\title{
Integrated Farming System: A Profitable Venture for Tribal farmers in Southern Rajasthan
}

\author{
Hari Singh* and G.L. Meena \\ Department of Agricultural Economics \& Management, MPUAT, Udaipur, India \\ *Corresponding author: singhhari71@gmail.com (ORCID ID: 0000-0002-7908-6470)
}

Received: $19-03-2021$

Revised: $17-05-2021$

Accepted: 16-06-2021

\begin{abstract}
The present study was conducted to evaluate the improved integrated farming system performance at the fields of 30 selected tribal farmers of three selected villages of Vallabhnagar tehsil of Udaipur district (Rajasthan) during 2018-19 and compared with the benchmark year 2015-16. Various interventions from MPUAT experts were provided regarding inputs and their timely use and the training programs for these farmers. It was concluded that during 2018-19 FS IV (Crop + Dairy + Vegetable) and FS V (Crop + Dairy + Vegetable + Fruit Orchard) were highly efficient as these systems gave the highest returns per rupee of investment. In contrast, FS VIII (Crop + Dairy + Goat + Vegetable + Fruit Orchard) was efficient in terms of employment generation as it leads to the generation of 463 man-days. As a result, higher profitability and productivity with the lesser cost of cultivation of improved integrated farming system were obtained compared to the existing integrated farming system during the benchmark year.

\section{Highlights}

( An integrated farming system is a way of farming to optimize the use of resources to get better returns at the farm level.

0 The present study proved that the use of dairy, olericulture, and horticultural components, and the cropping components proved efficient in terms of income and employment generation.
\end{abstract}

Keywords: Integrated Farming System, cropping system, productivity, profitability and employment

In India, increasing population and urbanization had led to a decrease in the area for cultivation of crops. The average size of the landholding has declined to 1.08 hectare during 2015-16, from 1.16 ha and 2.28 hectare during 2010-11 and 1970-71, respectively (Agricultural Census of India, 2015). If this trend continues, India's average size would be a mere 0.68 ha in 2020 and would be further reduced to 0.32 ha in 2030 (Agricultural Census of India, 2011). The income of a farmer from the cropping system alone is not sufficient to meet his requirements. In this direction, the farming system needs to be integrated. Integration refers to combining two things so that one component becomes a part of another component. Ponnusamy and Devi in 2017, narrated in their study that the inter-dependent-interlocking nature of Integrated
Farming System involves the use of primary and secondary products of one component as basic input of another component. It makes both components as mutually integrated units. Therefore, IFS may play an important role in doubling farmer's income. The main aim of IFS includes maximization of yield further to ensure steady and stable income at higher levels, amelioration of component's productivity, and the achievement of agroecological equilibrium. IFS also help in increasing natural resource use efficiency by early recycling of nutrients and mitigating the negative impact of farming system

How to cite this article: Singh, H. and Meena, G.L. (2021). Integrated Farming System: A Profitable Venture for Tribal farmers in Southern Rajasthan. Economic Affairs, 66(2): 349-353.

Source of Support: None; Conflict of Interest: None (6) 
on the environment. An economic assessment of farming systems aims to find the magnitude of profits from each component of the farming system and enhance the utilization capacity of locally available resources (Singh et al. 2011). Keeping in view of all these factors, the present study focuses on farmers' economics and employment generation through the integrated farming system in three selected villages of Vallabhnagar tehsil of Udaipur district in Rajasthan.

\section{MATERIALS AND METHODS}

The present study was conducted in three villages having more than 80 percent of the tribal population, namely Udakheda, Siyakhedi, and Gumanpura of Vallabhnagar tehsil at Udaipur district (Rajasthan) to study profitability and productivity of improved Integrated Farming System during the year 201819 in comparison to the year 2015-16 which was taken as a benchmark year for the study. Under an improved farming system, various inputs like hybrid seeds of vegetables and cereals, improved breeds of chicks, plantlets of fruits, etc. were provided to the selected farmers of the area. The selected farmers undertook the improved IFS system undertook the improved IFS system undertook the improved IFS system undertook the improved IFS system under the supervision of experts of the Directorate of Research, MPUAT, Udaipur. A sample of 30 tribal farmers of the study area were purposively selected for study in the manner as shown in table 1.
Total cost, gross returns, and net returns, along with returns per rupee investment were calculated by taking an average of the selected farmers.

Net returns:

$$
N R_{i j}=G R_{i j}-T C_{i j}
$$

Where,

$N R_{i j}=$ Net returns obtained in $i^{\text {th }}$ farming system through $j^{\text {th }}$ activities,

$G R_{i j}=$ Gross returns obtained in $i^{\text {th }}$ farming system through $j^{\text {th }}$ activities,

$T C_{i j}=$ Total cost incurred in $i^{\text {th }}$ farming system through jth activities.

\section{Returns per rupee investment}

$$
R P i=G I i / T C P i+T C R i
$$

Where,

$R P I i=$ Returns per rupee investment by $i^{\text {th }}$ farming system,

$T C P i=$ Total cost incurred in $i^{\text {th }}$ farming system through $j^{\text {th }}$ activities,

TCR $i=$ Total cost of raw material used in $j^{\text {th }}$ activities under $i^{\text {th }}$ farming system

The simple descriptive analysis was used to calculate the frequency, average values, and percentages of different characteristics of the farmers in the study.

Table 1: Number of respondents selected

\begin{tabular}{llcccc}
\hline S1. & \multirow{2}{*}{ Village } & Number of & \multicolumn{2}{c}{ Existing Farming Systems in Benchmark Year 2015-16 } \\
\cline { 4 - 6 } No. & & Farmers & FS I (Crop + Dairy) & FS II (Crop + Dairy + Goat) & FS III (Crop + Goat) \\
\hline 1 & Udakheda & 14 & 2 & 9 & 3 \\
2 & Siyakhedi & 10 & 5 & 5 & 0 \\
3 & Gumanpura & 6 & 0 & 6 & 0 \\
\hline
\end{tabular}

\begin{tabular}{llcccccc}
\hline & & \multicolumn{5}{c}{ Improved Farming Systems during 2018-19 } \\
\cline { 3 - 7 } $\begin{array}{l}\text { S1. } \\
\text { No. }\end{array}$ & Village & $\begin{array}{c}\text { Number of } \\
\text { Farmers }\end{array}$ & $\begin{array}{c}\text { FS IV (Crop } \\
\text { + Dairy + } \\
\text { Vegetable) }\end{array}$ & $\begin{array}{c}\text { FS V (Crop } \\
+ \text { Dairy + } \\
\text { Vegetable + } \\
\text { Fruit Orchard) }\end{array}$ & $\begin{array}{c}\text { FS VI (Crop } \\
\text { + Goat + } \\
\text { Vegetable + } \\
\text { Poultry) }\end{array}$ & $\begin{array}{c}\text { FS VII (Crop + } \\
\text { Dairy + Goat + } \\
\text { Vegetable) }\end{array}$ & $\begin{array}{c}\text { FS VIII (Crop } \\
\text { + Dairy + Goat } \\
\text { + Vegetable + } \\
\text { Fruit Orchard) }\end{array}$ \\
\hline 1 & Udakheda & 14 & 1 & 1 & 3 & 3 & 3 \\
2 & Siyakhedi & 10 & 3 & 2 & 0 & 0 & 1 \\
3 & Gumanpura & 6 & 0 & 0 & 0 & 0 & 2 \\
\hline
\end{tabular}


Integrated Farming System: A Profitable Venture for Tribal farmers in Southern Rajasthan
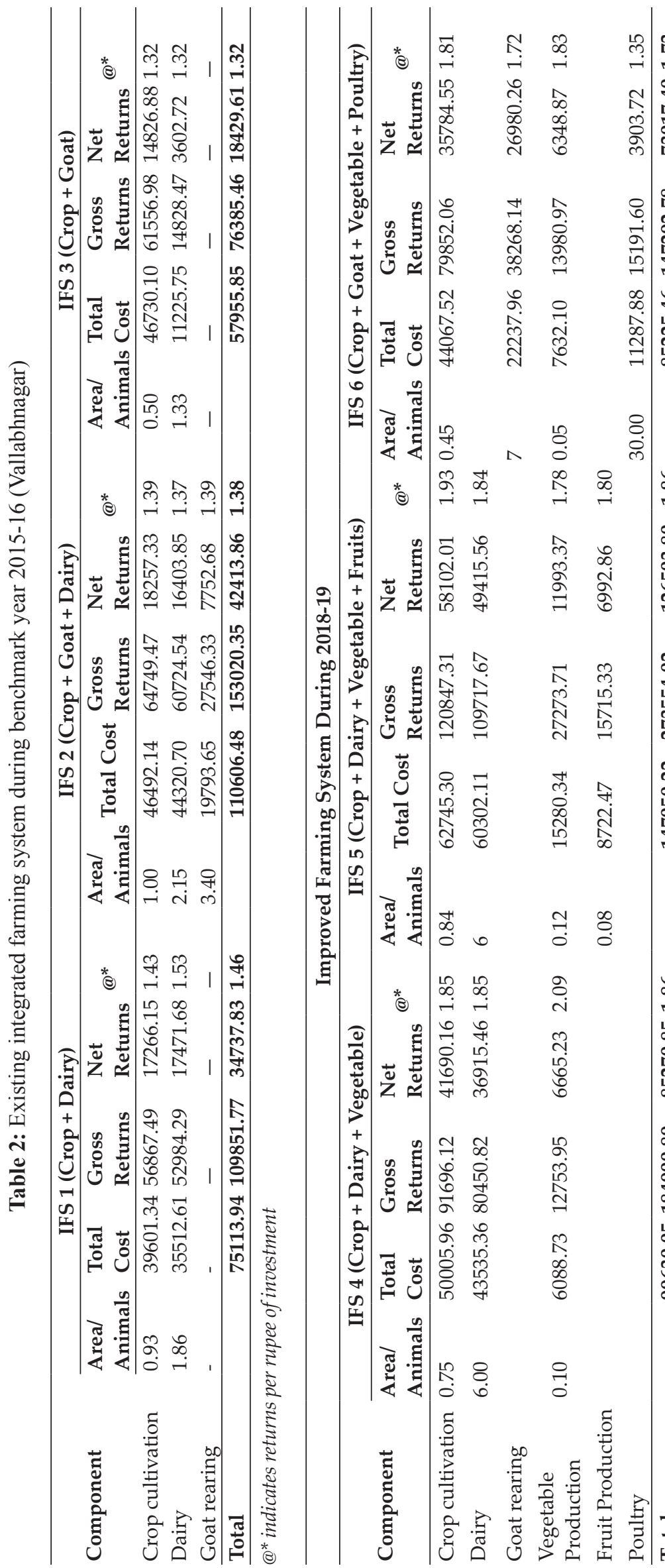

ment

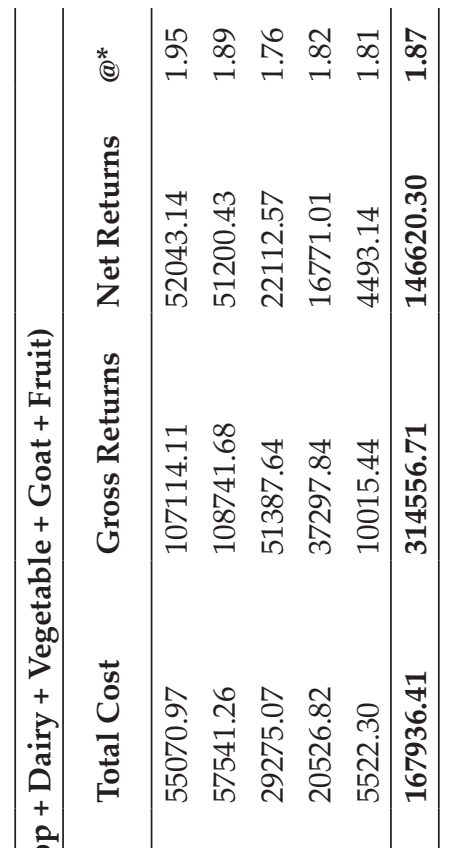

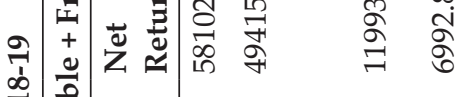

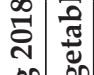

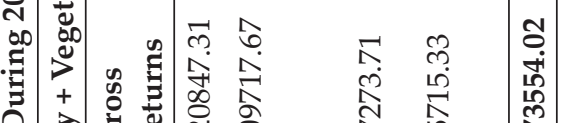

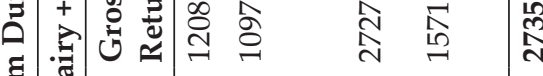

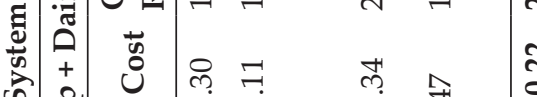

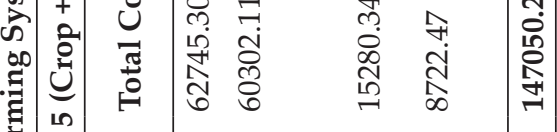

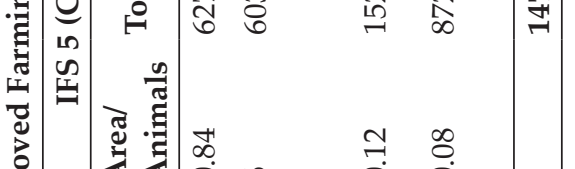

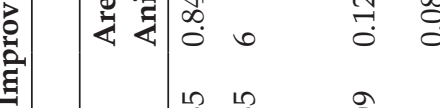

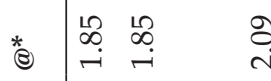

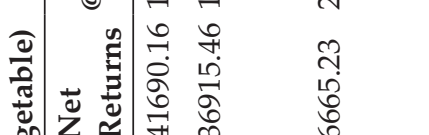

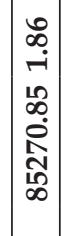

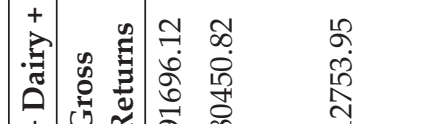

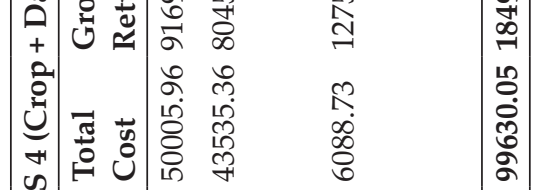

吕

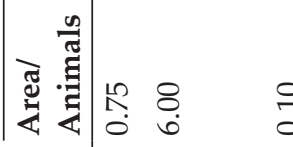

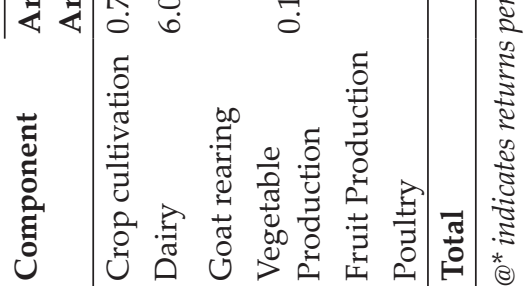

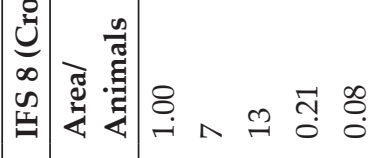

• *)

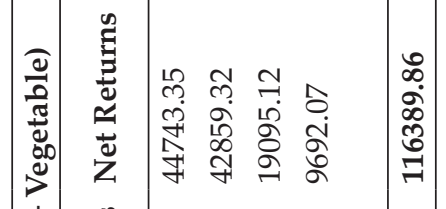

索

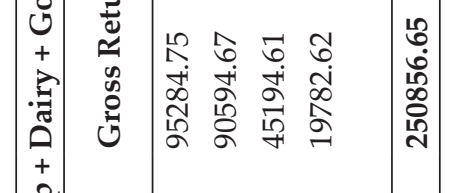

年

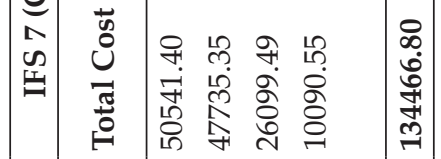

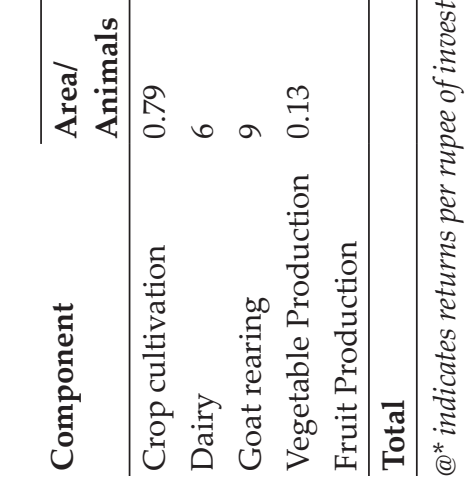




\section{RESULTS AND DISCUSSION}

The survey was conducted for the need assessment of farmers during the benchmark year 2015-16. On the basis of the needs of the farmers, the existing farming system was improved by various interventions of MPUAT experts. Improved seeds of pulses, cereals, and oilseed crops along with seasonal varieties of vegetable crops viz. tomato, brinjal, bottle guard, ridge guard, bitter guard, pea, spinach, fenugreek, coriander, seedlings of fruit crops viz. citrus, ber, papaya, etc. were provided to the selected farmers of the area and training programs were also organized for improving their skills in handling farming system. Both the farming systems were analyzed, and compared on the basis of returns and employment generation. The results of the analysis comparing different farming systems are presented in Table 2.
From Table 2, it can interpreted that highest returns per rupee investment were obtained in farming system 1 i.e. 1.46 as compared to FS 2 and FS 3 under benchmark/ existing farming systems during 201516. With improved technologies and varieties/ seeds the net returns and returns per rupee investment varied. During 2018-19, the net returns were highest obtained of ₹ 146620.30 with 1.87 returns per rupee investment under farming system 8 followed by farming system 4 of ₹ 126503.80, farming system 7 of ₹ 116389.86 , farming system 3 of 85270.85 and farming system 5 of 73017.40 .

Table 3 summarized the total cost gross returns and net returns and returns per rupee investment and employment generated by the integrated farming systems.

The study revealed that the existing integrated farming systems II (Crop + Dairy + Goat) during the

Table 3: Economics of Existing and improved integrated farming system

\begin{tabular}{llllll}
\hline Farming System & Total Cost (₹) & Gross Returns (₹) & Net Returns (₹) & $\begin{array}{l}\text { Returns per rupee } \\
\text { investment }\end{array}$ & $\begin{array}{l}\text { Employment } \\
\text { (man days) }\end{array}$ \\
\hline \multicolumn{7}{l}{} & \multicolumn{1}{l}{ Existing IFS Benchmark Year (2015-16) } & & & \\
\hline FSI & 75113.94 & 109851.77 & 34737.83 & 1.46 & 177.19 \\
FSII & 110606.5 & 153020.34 & 42413.86 & 1.38 & 199.86 \\
FSIII & 57955.85 & 76385.45 & 18429.61 & 1.32 & 67.46 \\
\hline & Improved IFS (2018-19) & & & \\
\hline FSIV & 99630.05 & 184900.89 & 85270.85 & 1.86 & 304.32 \\
FSV & 147050.2 & 273554.01 & 126503.80 & 1.86 & 259.84 \\
FSVI & 85225.46 & 147292.77 & 73017.40 & 1.73 & 188.22 \\
FSVII & 134466.8 & 250856.65 & 116389.90 & 1.87 & 367.19 \\
FSVIII & 167936.4 & 314556.70 & 146620.30 & 1.87 & 463.07 \\
\hline
\end{tabular}

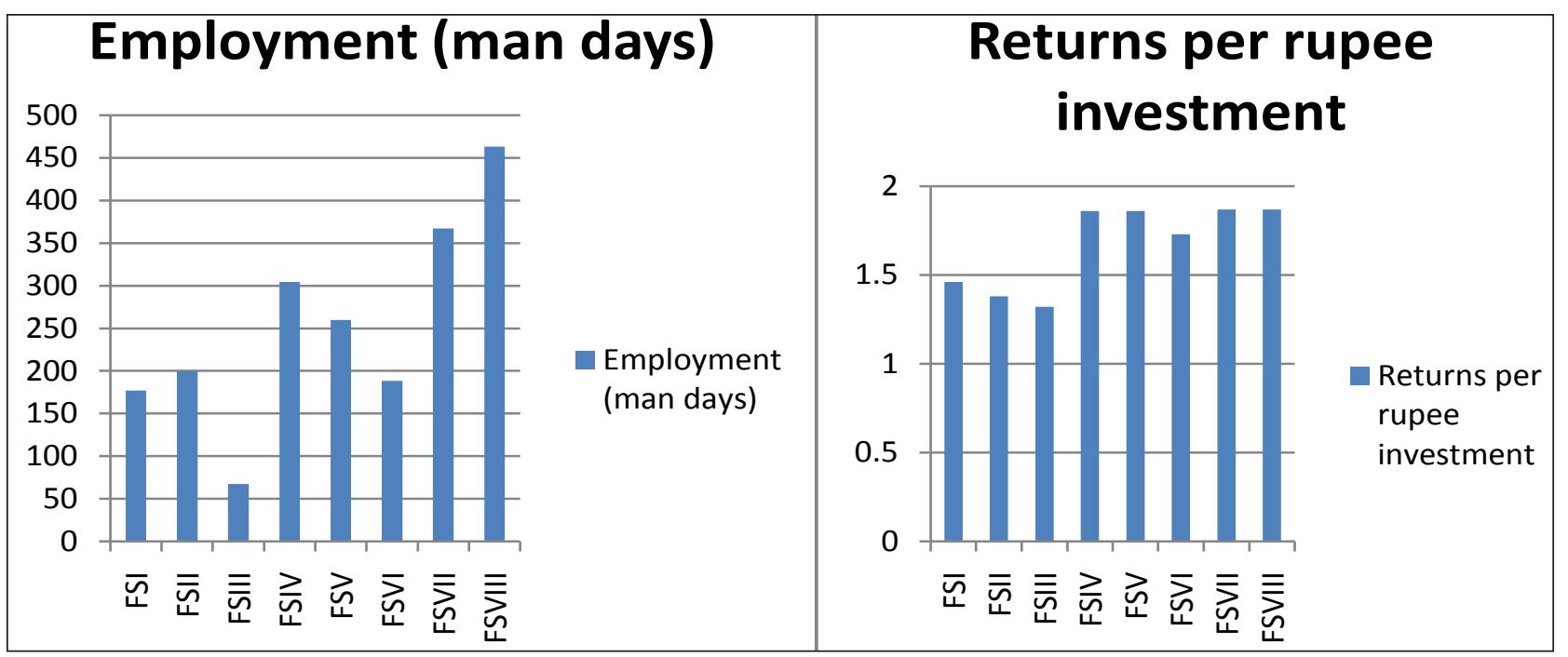

Fig. 1: Performance of Different Farming Systems 
2015-16 was more efficient in terms of employment, whereas FS I (Crop + Dairy) was highly efficient gave the highest returns per rupee of investment of 1.46. During 2018-19, FS IV (Crop + Dairy + Vegetable) and FS V (Crop + Dairy + Vegetable + Fruit Orchard) were highly efficient as these systems gave the highest returns per rupee of investment. In contrast, FS VIII (Crop + Dairy + Goat + Vegetable + Fruit Orchard) was efficient in terms of employment generation as it leads to the generation of 463 mandays because of the inclusion of five components of farming efficiently and effectively. The results can be compared as shown in Fig. 1. Therefore, substantial additional income could be generated by practicing different enterprise combinations based on farmers' location specificity and capability (Rangasamy et al. 1995; Ponnusamy, 2006).

\section{CONCLUSION}

The present study revealed that the integration of various farming system approaches efficiently and effectively farming systems approaches efficiently and effectively would help improve the livelihood of the farmer. The most notable advantage of utilizing low-cost/no-cost material at the farm level for recycling is that it will reduce the production cost and improve the farm income considerably. It will not only provide better returns but also led to better utilization of products which we consider as waste. So, it may prove fruitful in sustainable management of resources under farming system to have the least impact on the environment. This will improve the adoption of a full integration farming system, and poverty can be eradicated in the country's rural areas.

\section{ACKNOWLEDGEMENTS}

The authors express their gratitude towards RKVY, GOI for providing financial assistance as this research paper is part of RKVY project "Development and Dissemination of Economically Viable Farming Systems for Farmers of Tribal Area of Southern Rajasthan" Directorate of Research, MPUAT, Udaipur.

\section{REFERENCES}

Agricultural Census of India. 2011. Ministry of Agriculture and Farmer's Welfare, Government of India, New Delhi.

Agricultural Census of India. 2015. Ministry of Agriculture and Farmer's Welfare, Government of India, New Delhi.

Bahera, U.K. and Mahapatra, I.C. 1999. Income and employment generation of small and marginal farmers through integrated systems. Indian J. Agron., 44(3): 431439.

Kamble, A.S., Yogeesh, L.N., Prashant, S.M., Peer, P.S. and Desai, B.K. 2017. Integrated Farming System: Profitable farming to small farmers. Int. J. Curr.Micro. App. Sci., 66(10): 2819-2824.

Ponnusamy, K. 2006. Multidimensional analysis of integrated farming system in the coastal agro-eco system of Tamil Nadu. Ph.D. Thesis. NDRI (Deemed University), Karnal, Haryana.

Ponnusamy, K. and Devi, M.K. 2017. Impact of Integrated Farming System approach on Doubling Farmer's Income. Agric. Econ. Res. Rev., 30(4):233-240.

Rangasamy, A., Venkitasamy, R., Jayanthi, C., Purushothaman, S. and Palaniappan, S.P. 1995. Rice based farming system: A viable approach. Indian Farm., 46(4): 27-29.

Singh, H. and Burark, S.S. 2016. Income and employment generation under existing farming systems in tribal dominated Banswara district of Southern Rajasthan. Econ. Aff., 61(1): 119-125.

Singh, H. and Burark, S.S. 2016. Income and employment generation under existing farming systems in tribal dominated Banswara district of Southern Rajasthan. Econ. Aff. 61(1): 119-125.

Singh, H., Burark, S.S., Sharma, L., Meena, G.L., Bhushan, B. and Meena, K. 2016. Constraints faced by the households in existing farming systems in Chittorgarh and Banswara districts of Southern Rajasthan. J. Anim. Res., 6(6): 10211035.

Singh, J.P., Gangwar, B., Pandey, D.K. and Kochewad, S.A. 2011. Integrated farming system model for small farm holders of Western Plain Zone of Uttar Pradesh. PDFSR Bulletin No. 05. Project Directorate for Farming Systems Research, Modipuram, Meerut, India, pp. 58.

Soni, R.P., Katoch, M. and Ladohia, R. 2014. Integrated farming systems- a review. IOSR J. Agric. Vet. Sci., 7(10): 36-42. 
